\title{
Kualitas Semen Segar dan Produksi Semen Beku Sapi Pejantan Madura pada Musim yang Berbeda
}

\author{
The Quality of Fresh Semen and Frozen Semen Production Madura Bulls in Different Seasons
}

Komariah $^{1 *}$, R. I. Arifiantini' ${ }^{2}$ M. Aun ${ }^{3}$, \& E. Sukmawati ${ }^{4}$

${ }^{1,3}$ Laboratorium Ilmu Produksi Ternak Ruminansia Besar,

FAPET IPB. Jl. Agatis Kampus IPB Darmaga Bogor 16680

${ }^{2}$ Divisi Reproduksi dan Kebidanan, Departemen Klinik, Reproduksi dan Patologi, FKH IPB

Rasamala Kampus IPB Darmaga Bogor 16680

${ }^{4}$ Balai Inseminasi Buatan Lembang

Jl. Kayu Ambon, Kayuambon, Lembang, Bandung 40391

*Corresponding author: komariah_purjati@yahoo.com

(Received 14-12-2019; Revised 30-12-2019; Accepted 06-01-2020)

\begin{abstract}
Variation among breed and seasons were speculated influence to the quality of fresh semen bull. The aim of this research was to evaluate the quality of fresh semen and the potential of frozen semen production madura bull in rainy and dry seasons at Lembang Artificial Insemination Center (AIC). This research used secondary data of semen production from January to December 2015. In this research were used 5 bulls. The observed variables for macroscopic characteristics of fresh semen were volume, color, $\mathrm{pH}$, and consistency, and microscopic characteristics of fresh semen were mass movement, motility, and concentration of spermatozoa. It could be concluded that the quality of fresh semen and the potential of frozen semen production of several madura bulls were relatively different in the rainy and dry seasons.
\end{abstract}

Keywords: madura cattle, individual performance, semen quality.

\begin{abstract}
ABSTRAK
Variasi bangsa dan musim berpengaruh terhadap kualitas semen segar sapi. Penelitian ini bertujuan mengevaluasi kualitas semen segar dan produksi semen beku beberapa individu sapi pejantan madura pada musim hujan dan musim kemarau di Balai Inseminasi Buatan (BIB) Lembang, Bandung, Jawa Barat. Penelitian ini menggunakan data sekunder produksi semen dari bulan Januari hingga Desember 2015. Pejantan yang digunakan sebanyak 5 ekor pada umur tiga sampai lima tahun. Peubah yang diamati meliputi karakteristik makroskopis yaitu volume, warna, pH, dan konsistensi serta karakteristik mikroskopis yaitu gerakan massa, motilitas dan konsentrasi spermatozoa. Data dianalisis dengan uji independent sample T-test dan data disajikan dalam bentuk rerata ( \pm simpangan baku (sd). Hasil penelitian menunjukkan bahwa kualitas semen segar dan potensi produksi semen beku beberapa sapi pejantan madura relatif berbeda pada musim hujan dan musim kemarau. Sapi 2 menghasilkan potensi rerata produksi semen beku relatif tinggi pada musim hujan $153.31 \pm 76.51$ straw tetapi cenderung rendah pada musim kemarau $99.14 \pm 64.46$ straw. Sapi 3 menghasilkan produksi semen beku relatif tinggi pada musim kemarau 160.25 \pm 59.10 straw. Kualitas semen segar dan produksi semen beku sapi 5 cenderung rendah pada kedua musim.
\end{abstract}

Kata kunci: kualitas semen, performa individu, sapi madura. 


\section{PENDAHULUAN}

Sapi potong merupakan salah satu komoditas ternak yang perkembangannya cukup pesat dan sangat mendukung perekonomian masyarakat. Pengembangan komoditas sapi potong di Indonesia diharapkan dapat mencukupi kebutuhan produk daging dari maraknya impor sapi potong. Kebutuhan produk daging di Indonesia setiap tahun semakin meningkat. Sapi madura adalah sapi potong lokal asli Indonesia yang memiliki ketahanan terhadap agroekosistem kering dan mampu berkembang baik di pulau madura (Wijono dan Setiadi 2004).

Sapi madura menjadi rumpun sapi potong lokal melalui pengaruh alam dan lingkungan, sehingga mempunyai keseragaman karakteristik yang menonjol di antara rumpun sapi potong lokal lainnya. Keunggulan sapi madura secara genetik memiliki sifat toleran terhadap iklim panas dan lingkungan marjinal, tahan serangan caplak, adaptasi yang tinggi terhadap kualitas pakan yang rendah, serta kebutuhan pakan lebih sedikit dibandingkan dengan sapi impor (Nurgiartiningsih 2010). Kontribusi sifat-sifat genetik sapi zebu pada sapi madura tersebut merupakan suatu keunggulan yang patut untuk dikembangkan, salah satunya yaitu dengan adanya Inseminasi Buatan (IB).

IB merupakan salah satu teknologi tepat guna yang dapat meningkatkan produktivitas dan mutu genetik ternak sapi potong dengan memanfaatkan potensi pejantan unggul agar dapat membuahi lebih dari satu induk (Susilawati 2013). Keberhasilan inseminasi buatan ditentukan oleh kualitas semen beku pejantan yang juga dipengaruhi oleh karakteristik semen segarnya melalui pemeriksaan baik makroskopis maupun mikroskopis. Kualitas spermatozoa setiap bangsa dan masing-masing ternak berbeda-beda. Faktor genetik, umur, bangsa ternak dan variasi individu dapat mempengaruhi ketahanan sel spermatozoa terhadap cekaman suhu (thermal shock) pada saat berlangsunya proses thawing (Cotter et al. 2005). Indonesia sebagai negara yang beriklim tropis memiliki 2 musim, yakni musim hujan dan musim kemarau. Koivisto et al. (2009) mengatakan bahwa musim dapat berpengaruh terhadap kualitas semen lebih dari $2 \%$. Penelitian ini bertujuan mengevaluasi kualitas semen segar dan produksi semen beku beberapa sapi pejantan madura pada musim hujan dan musim kemarau di Balai Inseminasi Buatan (BIB) Lembang, Bandung, Jawa Barat.

\section{MATERI DAN METODE}

Penelitian ini merupakan penelitian noneksperimental menggunakan data sekunder produksi semen pejantan sapi madura. Data sekunder yang digunakan berasal dari Balai Inseminasi Buatan Lembang, Bandung, Jawa Barat. Perolehan dan pengolahan data dilakukan selama 3 bulan dari bulan Desember 2017 hingga Februari 2018.

Bahan yang digunakan dalam penelitian ini adalah data sekunder periode produksi semen pejantan sapi madura selama 12 bulan dari bulan Januari 2015 hingga Desember 2015. Penampungan semen pejantan sapi madura menurut data produksi BIB Lembang tahun 2015 dilakukan setiap hari Senin dan Kamis. Proses penampungan semen di BIB Lembang menggunakan metode vagina buatan atau Artificial Vagina (AV). Kegiatan penampungan meliputi persiapan pejantan, persiapan vagina buatan, dan pelaksanaan penampungan. Segera setelah penampungan, dilakukan pemeriksaan semen segar. Pemeriksaan semen segar dilakukan berdasarkan Standar Operasional Prosedur (SOP) BIB Lembang tahun 2010 tentang pemeriksaan dan pengujian mutu semen.

Prosedur penelitian ini dilakukan dengan metode studi kasus terhadap objek penelitian 5 sapi pejantan madura. Sapi pejantan madura terdiri atas kode sapi 161001, 161002, 161203, 161204, dan 161205. Kode sapi pejantan madura tersebut secara berurutan diubah menjadi sapi 1, sapi 2, sapi 3 , sapi 4, dan sapi 5 sesuai nomor urut pejantan. Penetapan iklim pada penelitian ini yakni musim hujan dan musim kemarau dilakukan dengan melihat intensitas curah hujan di Jawa Barat. Awal musim kemarau ditetapkan berdasarkan jumlah curah hujan bulanan yakni kurang dari $150 \mathrm{~mm}^{3}$, sebaliknya awal musim hujan ditetapkan berdasarkan curah hujan lebih dari $150 \mathrm{~mm}^{3}$. Musim kemarau tahun 2015 di Jawa Barat bermula pada bulan April hingga Oktober. Tabel 1 menyajikan curah hujan dan hari hujan Provinsi Jawa Barat tahun 2015 (BPS 2016).

Tabel 1. Data jumlah hari hujan dan curah hujan menurut bulan tahun 2015 di provinsi jawa barat

\begin{tabular}{lcc}
\hline Bulan & Hari Hujan (hari) & Curah Hujan $\left(\mathrm{mm}^{3}\right)$ \\
\hline Januari & 26 & 324.6 \\
Februari & 16 & 150.6 \\
Maret & 13 & 162.4 \\
April & 17 & 121.8 \\
Mei & 20 & 119.5 \\
Juni & 16 & 87.9 \\
Juli & 11 & 29.1 \\
Agustus & 4 & 80.3 \\
September & 1 & 31.8 \\
Oktober & 4 & 33.5 \\
November & 22 & 284.1 \\
Desember & 18 & 283.5 \\
\hline
\end{tabular}

\section{Koleksi dan Pengolahan Data}

Data yang digunakan dalam penelitian ini merupakan data sekunder yang dilaporkan setiap bulannya oleh BIB Lembang. Pengambilan data yang digunakan dalam penelitian ini adalah data semen segar secara makroskopis dan mikroskopis. Data semen segar secara makroskopis meliputi volume semen, warna semen, $\mathrm{pH}$ semen, dan konsistensi semen. Data semen segar secara mikroskopis meliputi gerakan massa spermatozoa, motilitas spermatozoa, dan konsentrasi spermatozoa. Keseluruhan data penampungan semen segar kemudian ditabulasikan. Individu sapi pejantan madura yang dipilih merupakan individu sapi pada umur produktif. 
Peubah yang diamati:

\section{Peubah}

1. Volume semen segar $\left(\mathrm{mL}^{-1}\right.$ ejakulat $\left.{ }^{-1}\right)$ merupakan jumlah milliliter semen setiap penampungan;

2. Warna semen segar merupakan keadaan fisik warna semen segar yang terkoleksi;

3. $\mathrm{pH}$ semen segar merupakan ukuran keasaman atau kebasaan dari semen segar;

4. Konsistensi semen segar merupakan tingkat kekentalan fisik semen segar yang terkoleksi;

5. Gerakan massa spermatozoa merupakan evaluasi yang dilakukan untuk melihat spermatozoa yang bergerak bersama-sama;

6. Motilitas spermatozoa (\%) merupakan penilaian gerakan spermatozoa secara individu, baik kecepatan maupun perbandingan antara pergerakan aktif progresif dengan gerakan-gerakan spermatozoa yang lainnya;

7. Konsentrasi spermatozoa (juta ${ }^{-1} \mathrm{~mL}^{-1}$ ) merupakan banyaknya jumlah spermatozoa per milliliter semen.

\section{Analisis Data}

Analisis data dilakukan dengan independent sample T-test terhadap data semen segar 5 sapi pejantan madura pada musim yang berbeda (hujan, kemarau). Data semen segar berupa data kuantitatif (volume semen, $\mathrm{pH}$ semen, motilitas spermatozoa, konsentrasi spermatozoa) dan data kualitatif (warna semen, konsistensi semen, gerakan massa spermatozoa). Data semen segar dan produksi semen beku disajikan dalam bentuk rerata \pm simpangan baku (SD).

\section{HASIL DAN PEMBAHASAN}

\section{Kualitas Semen Segar}

Evaluasi kualitas semen segar sangat diperlukan untuk mengetahui kualitas spermatozoa yang dihasilkan oleh setiap individu ternak. Semen segar yang telah memenuhi persyaratan dapat diencerkan dan diproses menjadi semen beku yang layak untuk diinseminasikan. Kualitas semen segar terbagi atas aspek makroskopis dan mikroskopis. Aspek makroskopis meliputi volume semen, warna semen, $\mathrm{pH}$ semen, dan konsistensi semen, sedangkan aspek mikroskopis yaitu gerakan massa spermatozoa, motilitas spermatozoa, dan konsentrasi spermatozoa.

\section{Karakteristik Makroskopis}

\section{Volume Semen}

Volume semen adalah salah satu titik ukur yang digunakan untuk mengetahui kualitas suatu semen sapi pejantan dalam 1 kali ejakulat koleksi semen. Nilai rerata volume semen sapi pejantan madura dapat dilihat pada Tabel 2.

Penampungan semen sapi pejantan madura pada musim hujan mempunyai nilai rerata volume semen cukup tinggi pada sapi 1 , sapi 2 , sapi 4 , dan sapi 5 , berbeda halnya dengan sapi 3 yang hanya menghasilkan $4.17 \pm 1.27 \mathrm{~mL}-1$ ejakulat-1. Volume semen sapi 5 di musim kemarau terlihat tidak berbeda dengan sapi 1 dan sapi 4 namun berbeda dengan sapi 2 dan sapi 3 yang menghasilkan volume semen lebih rendah (Tabel 2). Garner dan Hafez (2000) menjelaskan bahwa perbedaan musim dan lamanya penyinaran dapat
Tabel 2. Volume semen sapi pejantan madura di BIB Lembang pada musim hujan dan musim kemarau

\begin{tabular}{llc}
\hline Sapi & Musim hujan & Musim kemarau \\
\cline { 2 - 3 } & \multicolumn{2}{c}{$\mathrm{mL}^{-1}$ ejakulat $^{-1}$} \\
\hline 1 & $5.27 \pm 1.20 \mathrm{a}$ & $5.19 \pm 1.21 \mathrm{~b}$ \\
2 & $5.41 \pm 1.49 \mathrm{a}$ & $4.35 \pm 1.48 \mathrm{a}$ \\
3 & $4.17 \pm 1.27 \mathrm{~b}$ & $4.55 \pm 1.16 \mathrm{a}$ \\
4 & $5.42 \pm 1.27 \mathrm{a}$ & $6.04 \pm 1.57 \mathrm{c}$ \\
5 & $5.54 \pm 1.64 \mathrm{a}$ & $5.62 \pm 1.47 \mathrm{bc}$ \\
\hline
\end{tabular}

Angka yang diikuti huruf berbeda pada kolom yang sama menunjukkan perbedaan nyata berdasarkan pengujian dengan taraf uji $5 \%$.

memengaruhi produksi FSH sehingga menghambat proses spermatogenesis di dalam testis. Volume semen sapi 3, sapi 4 dan sapi 5 relatif meningkat pada musim kemarau. Semakin tinggi tingkat curah hujan maka akan berdampak pada volume semen yang rendah, sebaliknya pada tingkat curah hujan yang rendah (Khairi et al. 2014). Nilai rerata volume semen kelima sapi pejantan madura walaupun relatif bervariasi pada setiap individu dan perbedaan musim namun termasuk dalam kisaran volume semen sapi yang normal. Arifiantini (2012) menyatakan bahwa sapi pejantan normalnya menghasilkan rerata volume semen 4-8 mL.

Sapi madura merupakan sapi lokal sehingga mempunyai ukuran testis dan kelenjar aksesoris yang lebih kecil bila dibandingkan dengan sapi eksotik. Volume semen sapi pejantan menurut Garner dan Hafez (2000) dapat mencapai $15 \mathrm{~mL}^{-1}$ ejakulat $^{-1}$, namun untuk volume semen sapi lokal hanya mencapai 2-5 $\mathrm{mL}^{-1}$ ejakulat ${ }^{-1}$. Rerata volume semen sapi pejantan madura dalam hal ini relatif tinggi dari rumpun lokal sapi aceh umur 3-3.5 tahun dengan produksi rerata volume semen $3.82 \pm 0.47 \mathrm{~mL}^{-1}$ ejakulat ${ }^{-1}$ (Zulyazaini et al. 2016).

\section{Warna Semen}

Kualitas makroskopis warna pada semen sapi juga menjadi suatu hal yang menentukkan baik tidaknya kualitas semen. Semen yang diproduksi sapi pejantan madura di BIB Lembang terdiri atas beberapa kategori warna semen, yakni abnormal, kuning, krem, dan putih susu. Penampilan warna semen di musim hujan pada sapi 1 dan sapi 2 berbeda namun kisaran warna semen yang dihasilkan adalah sama yakni krem hingga putih susu. Produksi warna semen sapi pejantan madura di musim kemarau tidak berbeda pada kelima sapi dibandingkan musim hujan (Tabel 3). Warna semen dengan penampilan putih susu dan krem termasuk dalam kriteria warna semen yang baik dan normal. Hal ini sesuai dengan pernyataan Feradis (2010) bahwa semen sapi normalnya berwarna putih susu atau krem keputihan serta keruh. Kepekatan atau kekeruhan warna semen sapi mempunyai sedikit hubungan dengan konsentrasi spermatozoa. Lestari et al. (2013) berpendapat bahwa semakin keruh warna semen biasanya jumlah spermatozoa per mililiter semen semakin banyak.

Warna semen sapi pejantan madura pada musim hujan dan musim kemarau dengan kriteria putih susu relatif dominan diikuti produksi semen berwarna krem. 
Tabel 3. Skor warna semen sapi pejantan madura di BIB Lembang pada musim hujan dan musim kemarau

\begin{tabular}{|c|c|c|}
\hline \multirow[t]{2}{*}{ Sapi } & Musim hujan & Musim kemarau \\
\hline & \multicolumn{2}{|c|}{ Skor Warna } \\
\hline 1 & $3.94 \pm 0.23 \mathrm{a}$ & $3.72 \pm 0.45$ \\
\hline 2 & $3.71 \pm 0.46 b$ & $3.67 \pm 0.66$ \\
\hline 3 & $3.76 \pm 0.61 \mathrm{ab}$ & $3.67 \pm 0.61$ \\
\hline 4 & $3.83 \pm 0.38 \mathrm{ab}$ & $3.67 \pm 0.61$ \\
\hline 5 & $3.56 \pm 1.09 \mathrm{ab}$ & $3.76 \pm 0.66$ \\
\hline
\end{tabular}

Skor warna: (1) abnormal; (2) kuning; (3) krem; (4) putih susu. Angka yang diikuti huruf berbeda pada kolom yang sama menunjukkan perbedaan nyata berdasarkan pengujian dengan taraf uji $5 \%$.

Sunami et al. (2017) dalam penelitiannya pada sapi limousin mengungkapkan bahwa warna semen putih susu mendominasi pada musim hujan dan musim kemarau, warna lain yaitu putih bening serta warna bening yang sangat jarang ditemukan. Penelitian lain yang dilakukan Aisah et al. (2017) pada rumpun lokal sapi bali juga mengungkapkan bahwa semen dengan warna putih susu mendominasi saat musim kemarau dibandingkan musim hujan.

\section{Nilai pH Semen}

Nilai $\mathrm{pH}$ semen sapi merupakan peubah yang sangat penting dan krusial sebagai penentu kehidupan spermatozoa di dalam semen. Nilai rerata $\mathrm{pH}$ semen beberapa individu sapi pejantan madura pada Tabel 4 di musim hujan tidak berbeda pada kelima sapi. Sapi 5 menunjukkan rerata nilai $\mathrm{pH}$ yang tinggi $6.72 \pm 0.17$ dibandingkan sapi 1 dan sapi 4 yang lebih rendah pada musim kemarau. Rentang nilai $\mathrm{pH}$ semen sapi pejantan madura dalam penelitian ini masih termasuk dalam kisaran $\mathrm{pH}$ semen yang normal. Semen sapi yang normal menurut Ax et al. (2000) mempunyai nilai $\mathrm{pH}$ berkisar antara 6.2-7.0. Nilai $\mathrm{pH}$ semen sapi pejantan madura pada musim hujan relatif merata dibandingkan nilai $\mathrm{pH}$ semen saat musim kemarau. Sunami et al. (2017) berpendapat bahwa tinggi rendahnya nilai $\mathrm{pH}$ semen berkaitan dengan keadaan konsentrasi spermatozoanya, konsentrasi spermatozoa yang tinggi akan berdampak pada $\mathrm{pH}$ semen yang cenderung asam dalam kisaran normal.

Derajat keasaman $(\mathrm{pH})$ semen sangat menentukan status kehidupan spermatozoa di dalam semen. Semakin rendah atau tingginya nilai $\mathrm{pH}$ suatu semen dari nilai $\mathrm{pH}$

Tabel 4. Nilai pH semen sapi pejantan madura di BIB Lembang pada musim hujan dan musim kemarau

\begin{tabular}{ccc}
\hline Sapi & Musim hujan & Musim kemarau \\
\hline 1 & $6.63 \pm 0.14$ & $6.61 \pm 0.15 \mathrm{a}$ \\
2 & $6.60 \pm 0.18$ & $6.66 \pm 0.15 \mathrm{ab}$ \\
3 & $6.61 \pm 0.14$ & $6.67 \pm 0.14 \mathrm{ab}$ \\
4 & $6.59 \pm 0.13$ & $6.64 \pm 0.16 \mathrm{a}$ \\
5 & $6.67 \pm 0.18$ & $6.72 \pm 0.17 \mathrm{~b}$ \\
\hline
\end{tabular}

Angka yang diikuti huruf berbeda pada kolom yang sama menunjukkan perbedaan nyata berdasarkan pengujian dengan taraf uji 5\%. normal akan memungkinkan spermatozoa lebih cepat mati. Semen segar sapi pejantan madura dalam penelitian ini mempunyai nilai $\mathrm{pH}$ semen yang relatif rendah dibanding rumpun lokal sapi aceh dengan nilai $\mathrm{pH}$ semen berkisar 6.67.0 (Zulyazaini et al. 2016). Nilai pH semen dapat berubah menjadi ke arah yang lebih asam karena adanya penimbunan asam laktat yang merupakan hasil metabolisme sel yaitu pemecahan fruktosa (Sugiarti et al. 2004).

\section{Konsistensi Semen}

Kualitas semen segar dapat ditentukan oleh konsistensi semennya. Konsistensi semen sapi pejantan madura berkisar dari kriteria semen yang encer hingga sedang. Nilai konversi rerata konsistensi semen individu sapi 3 pada musim hujan dan musim kemarau terlihat tinggi yakni $1.88 \pm 0.33$ dan $1.93 \pm 0.26$ berbeda dengan sapi 5 yang memiliki nilai rerata lebih rendah $1.22 \pm 0.42$ dan $1.12 \pm 0.33$ (Tabel 5). Konsistensi semen sapi 5 baik musim hujan ataupun musim kemarau lebih cenderung pada kriteria semen yang encer. Konsistensi semen yang encer tidak termasuk ke dalam konsistensi semen yang normal. Feradis (2010) mengatakan bahwa semen sapi normal memiliki konsistensi semen berkisar sedang hingga kental. Semen dengan konsistensi sedang dan kental biasanya merupakan kriteria standar semen yang dapat diproses untuk selanjutnya dijadikan semen beku. Semen yang baik derajat kekentalannya sedikit lebih kental dari susu, sedangkan semen yang buruk, baik warna maupun kekentalannya sama dengan air buah kelapa (Garner dan Hafez 2000).

Tabel 5. Skor konsistensi semen sapi pejantan madura di BIB Lembang pada musim hujan dan musim kemarau

\begin{tabular}{ccc}
\hline Sapi & Musim Hujan & Musim Kemarau \\
\cline { 2 - 3 } & \multicolumn{2}{c}{ Skor Konsistensi } \\
\hline 1 & $1.53 \pm 0.51 \mathrm{~b}$ & $1.53 \pm 0.50 \mathrm{~b}$ \\
2 & $1.60 \pm 0.50 \mathrm{~b}$ & $1.58 \pm 0.50 \mathrm{~b}$ \\
3 & $1.88 \pm 0.33 \mathrm{c}$ & $1.93 \pm 0.26 \mathrm{c}$ \\
4 & $1.59 \pm 0.50 \mathrm{~b}$ & $1.41 \pm 0.50 \mathrm{~b}$ \\
5 & $1.22 \pm 0.42 \mathrm{a}$ & $1.12 \pm 0.33 \mathrm{a}$ \\
\hline
\end{tabular}

Skor konsistensi: (1) encer; (2) sedang. Angka yang diikuti huruf berbeda pada kolom yang sama menunjukkan perbedaan nyata berdasarkan pengujian dengan taraf uji $5 \%$.

Konsistensi semen segar merupakan salah satu penilaian kualitas semen yang dinilai secara kualitatif. Hal ini dapat dilakukan dengan melihat kecepatan pergerakan semen yang dimiringkan dalam tabung. Arifiantini (2012) menjelaskan bahwa semen yang konsistensinya sedang adalah semen yang akan segera kembali ke dasar dengan kecepatan yang lebih lambat dibandingkan yang pertama, sementara itu sebagian semen masih menempel di dinding tabung.

\section{Karakteristik Mikroskopis}

\section{Gerakan Massa Spermatozoa}

Gerakan massa spermatozoa merupakan gerakan bersama-sama sekelompok sel spermatozoa dengan arah yang berlawanan dengan jarum jam. Koloni spermatozoa 
yang bergerak bersama dengan pergerakan yang cepat tentunya dapat meningkatkan kemungkinan terjadinya fertilisasi sel telur. Gerakan massa spermatozoa sapi pejantan madura di musim hujan pada sapi 3 dan sapi 4 menunjukkan nilai rerata konversi yang tinggi dan cenderung cepat $(++)$, sedangkan sapi 5 lebih rendah namun cenderung tidak cepat $(+)$ (Tabel 6). Nilai konversi rerata gerakan massa spermatozoa sapi 1, sapi 3, dan sapi 4 pada musim kemarau terlihat tinggi dan cenderung cepat $(++)$, berbeda dengan sapi 2 dan sapi 5 cenderung tidak cepat $(+)$. Gerakan massa spermatozoa dengan kriteria tidak cepat $(+)$ bukan termasuk pergerakan yang normal. Hal ini dijelaskan Campbell et al. (2003a) bahwa normalnya gerakan massa spermatozoa berkisar dari pergerakan yang cepat $(++)$ hingga sangat cepat $(+++)$.

Tabel 6. Skor gerakan massa spermatozoa sapi pejantan madura di BIB Lembang pada musim hujan dan musim kemarau

\begin{tabular}{ccc}
\hline Sapi & Musim Hujan & Musim Kemarau \\
\cline { 2 - 3 } & \multicolumn{2}{c}{ Skor Gerakan Massa } \\
\hline 1 & $1.81 \pm 0.40 \mathrm{ab}$ & $1.77 \pm 0.42 \mathrm{~b}$ \\
2 & $1.66 \pm 0.48 \mathrm{~b}$ & $1.32 \pm 0.47 \mathrm{a}$ \\
3 & $1.94 \pm 0.24 \mathrm{c}$ & $1.88 \pm 0.33 \mathrm{~b}$ \\
4 & $1.97 \pm 0.19 \mathrm{c}$ & $1.87 \pm 0.34 \mathrm{~b}$ \\
5 & $1.48 \pm 0.51 \mathrm{a}$ & $1.36 \pm 0.49 \mathrm{a}$ \\
\hline
\end{tabular}

Skor gerakan massa spermatozoa: (1) +; (2) ++. Angka yang diikuti huruf berbeda pada kolom yang sama menunjukkan perbedaan nyata berdasarkan pengujian dengan taraf uji 5\%.

Penampilan gerakan massa spermatozoa sapi pejantan madura relatif rendah dibandingkan rumpun lokal sapi aceh dengan kisaran pergerakan yang cepat $(++)$ hingga sangat cepat $(+++)$ (Zulyazaini et al. 2016). Pergerakan koloni spermatozoa yang semakin cepat dan pekat tentunya memungkinkan tingkat keberhasilan IB. Kriteria gerakan massa spermatozoa paling baik menurut Ax et al. (2000) yaitu $(+++)$ dengan pergerakan koloni spermatozoa sangat cepat dan pekat serta nilai $(++)$ dengan pergerakan cepat namun tipis atau tidak terlalu pekat.

\section{Motilitas Spermatozoa}

Nilai rerata persentase motilitas spermatozoa sapi 3 pada musim hujan terlihat tinggi berbeda dengan sapi 5 mempunyai nilai rerata yang rendah. Persentase motilitas spermatozoa di musim kemarau pada sapi 1, sapi 3 dan sapi 4 tidak berbeda kecuali pada sapi 2 dan sapi 5 yang menunjukkan rerata persentase yang lebih rendah (Tabel 7). Rerata nilai persentase motilitas spermatozoa yang normal hanya ditunjukkan oleh sapi 3 pada musim hujan yakni $71.32 \pm 4.14 \%$. Ax et al. (2000) berpendapat bahwa motilitas spermatozoa normalnya 70-90\% dengan pergerakan cepat. Rerata persentase motilitas spermatozoa relatif rendah bila dibandingkan rumpun sapi aceh dengan rerata persentase motilitas spermatozoa $77.28 \pm 3.17 \%$ (Zulyazaini et al. 2016).

Tinggi dan rendahnya persentase motilitas spermatozoa di dalam semen dapat dipengaruhi oleh suhu
Tabel 7. Motilitas spermatozoa sapi pejantan madura di BIB Lembang pada musim hujan dan musim kemarau

\begin{tabular}{clc}
\hline Sapi & \multicolumn{1}{c}{ Musim hujan } & Musim kemarau \\
\cline { 2 - 3 } & \multicolumn{2}{c}{$\%$} \\
\hline 1 & $66.25 \pm 11.79 \mathrm{~b}$ & $65.19 \pm 11.05 \mathrm{~b}$ \\
2 & $62.57 \pm 12.91 \mathrm{bc}$ & $55.35 \pm 12.53 \mathrm{a}$ \\
3 & $71.32 \pm 4.14 \mathrm{c}$ & $68.57 \pm 8.99 \mathrm{~b}$ \\
4 & $68.62 \pm 7.43 \mathrm{bc}$ & $67.22 \pm 8.56 \mathrm{~b}$ \\
5 & $55.74 \pm 18.33 \mathrm{a}$ & $52.00 \pm 18.26 \mathrm{a}$ \\
\hline
\end{tabular}

Angka yang diikuti huruf berbeda pada kolom yang sama menunjukkan perbedaan nyata berdasarkan pengujian dengan taraf uji $5 \%$.

dan kondisi cairan/plasma semen saat pemeriksaan. Ismaya (2014) dalam penelitiannya menjelaskan bahwa motilitas spermatozoa dipengaruhi oleh beberapa hal yaitu: suhu dingin akan menghambat motilitas, sedangkan suhu panas meningkatkan motilitas spermatozoa zat kimia. Urin dan kotoran yang mencemari semen dapat menurunkan motilitas spermatozoa; ejakulat pertama sesudah istirahat lama umumnya banyak sel spermatozoa yang mati.

\section{Konsentrasi Spermatozoa}

Banyaknya konsentrasi spermatozoa pada setiap individu sapi pejantan madura cukup beragam. Semen sapi pejantan madura di musim hujan dan musim kemarau pada sapi 3 menghasilkan nilai konsentrasi spermatozoa yang tinggi yakni $1222.94 \pm 364.82$ juta $^{-1} \mathrm{~mL}^{-1}$ dan 1 $235.71 \pm 284.85$ juta $^{-1} \mathrm{~mL}^{-1}$. Sapi 5 mempunyai rerata yang rendah di musim hujan dan musim kemarau masing-masing $648.15 \pm 250.37$ juta $^{-1} \mathrm{~mL}^{-1}$ dan $638.40 \pm 257.42$ juta $^{-1} \mathrm{~mL}^{-1}$ (Tabel 8). Nilai rerata konsentrasi spermatozoa semen sapi pejantan madura termasuk normal kecuali pada sapi 5. Hal ini sesuai dengan pendapat Campbell et al. (2003b) bahwa konsentrasi spermatozoa pada sapi jantan dewasa normalnya berkisar antara 800-1 200 juta $^{-1} \mathrm{~mL}^{-1}$ semen.

Tabel 8. Konsentrasi spermatozoa sapi pejantan madura di BIB Lembang pada musim hujan dan musim kemarau

\begin{tabular}{|c|c|c|}
\hline \multirow[t]{2}{*}{ Sapi } & Musim hujan & Musim kemarau \\
\hline & \multicolumn{2}{|c|}{ juta $^{-1} \mathrm{~mL}^{-1}$ ejakulat ${ }^{-1}$} \\
\hline 1 & $963.89 \pm 331.95 b$ & $1000.00 \pm 277.24 \mathrm{c}$ \\
\hline 2 & $1097.14 \pm 316.68 b c$ & $942.11 \pm 345.60 \mathrm{bc}$ \\
\hline 3 & $1222.94 \pm 364.82 \mathrm{c}$ & $1235.71 \pm 284.85 \mathrm{~d}$ \\
\hline 4 & $957.93 \pm 230.42 b$ & $830.37 \pm 285.78 b$ \\
\hline 5 & $648.15 \pm 250.37 \mathrm{a}$ & $638.40 \pm 257.42 \mathrm{a}$ \\
\hline
\end{tabular}

Angka yang diikuti huruf berbeda pada kolom yang sama menunjukkan perbedaan nyata berdasarkan pengujian dengan taraf uji $5 \%$.

Nilai rerata konsentrasi spermatozoa semen sapi pejantan madura relatif rendah dibandingkan rumpun lokal sapi aceh yaitu 1 194.00 \pm 52.25 juta $^{-1} \mathrm{~mL}^{-1}$ dengan kisaran antara 1 120-1 260 juta $^{-1} \mathrm{~mL}^{-1}$ (Zulyazaini et al. 2016). Konsentrasi spermatozoa semen sapi pejantan dipengaruhi oleh besar testis dan frekuensi penampungan semen yang 
dilakukan. Situmorang (2002) menyatakan bahwa perbedaan konsentrasi spermatozoa antar pejantan disebabkan karena kualitas genetik pada masing-masing pejantan.

\section{Produksi Semen Beku}

Semen segar yang diproduksi sapi pejantan pada akhirnya dikoleksi dan diproses menjadi semen beku untuk digunakan dalam inseminasi buatan. Baik atau tidaknya kualitas semen segar sapi pejantan untuk dijadikan semen beku dapat ditunjukkan oleh hasil rerata konsentrasi total spermatozoa dan jumlah produksi semen beku yang dihasilkan. Hasil rerata konsentrasi total spermatozoa dapat dilihat pada Tabel 9.

Tabel 9. Konsentrasi spermatozoa total sapi pejantan madura di BIB Lembang pada musim hujan dan musim kemarau

\begin{tabular}{|c|c|c|}
\hline \multirow[t]{2}{*}{ Sapi } & Musim Hujan & Musim Kemarau \\
\hline & \multicolumn{2}{|c|}{ juta $^{-1} \mathrm{~mL}^{-1}$ ejakulat ${ }^{-1}$} \\
\hline 1 & $5080.56 \pm 2078.13 b$ & $5143.49 \pm 1726.03 b c$ \\
\hline 2 & $5995.29 \pm 2509.38 b$ & $4400.00 \pm 2287.37 b$ \\
\hline 3 & $5246.47 \pm 2185.95 b$ & $5750.71 \pm 1999.85 c$ \\
\hline 4 & $5121.72 \pm 1465.57 b$ & $5141.30 \pm 2217.72 b c$ \\
\hline 5 & $3651.48 \pm 1959.05 a$ & $3722.28 \pm 1901.31 \mathrm{a}$ \\
\hline
\end{tabular}

Angka yang diikuti huruf berbeda pada kolom yang sama menunjukkan perbedaan nyata berdasarkan pengujian dengan taraf uji 5\%

Nilai rerata konsentrasi total spermatozoa sapi 5 di musim hujan lebih rendah $3651.48 \pm 1959.05$ juta $^{-1} \mathrm{~mL}^{-1}$ ejakulat $^{-1}$ berbeda dengan sapi 1 , sapi 2 , sapi 3 , dan sapi 4 yang dapat menghasilkan nilai rerata konsentrasi total yang lebih baik. Konsentrasi total spermatozoa di musim kemarau terlihat tinggi pada sapi 3 dengan nilai rerata $5750.71 \pm 1999.85$ juta $^{-1} \mathrm{~mL}^{-1}$ ejakulat ${ }^{-1}$ namun pada sapi 5 kembali menampilkan yang lebih rendah $3 \quad 722.28 \pm 1$ 901.31 juta $^{-1} \mathrm{~mL}^{-1}$ ejakulat ${ }^{-1}$ (Tabel 9). Hal ini sangat disayangkan melihat volume yang dihasilkan sapi 5 (Tabel 2) cukup tinggi, sedangkan konsentrasi spermatozoa yang dihasilkan lebih rendah dari individu sapi pejantan madura lainnya (Tabel 8). Garner dan Hafez (2000) berpendapat bahwa faktor stres diketahui dapat memengaruhi volume ejakulat dan konsentrasi spermatozoa. Penilaian konsentrasi spermatozoa sangat penting karena faktor inilah yang menggambarkan sifat-sifat sperma yang dipakai sebagai salah satu kriteria penentuan kualitas semen (Aisah et al. 2017).

Produksi semen beku yang dapat dihasilkan setiap individu sapi bergantung pada jumlah konsentrasi total spermatozoanya. Konsentrasi total spermatozoa di musim hujan terlihat berdampak pada rerata potensi produksi semen bekunya. Produksi semen beku sapi 5 pada musim hujan hanya $86.47 \pm 55.80$ straw berbeda dengan sapi 1 , sapi 2, sapi 3, dan sapi 4. Potensi produksi semen beku yang dihasilkan sapi 5 pada musim kemarau juga terlihat rendah $79.22 \pm 44.52$ straw dan hal ini juga tidak berbeda dengan sapi 2 yakni $99.14 \pm 64.46$ straw.

Data rerata konsentrasi total spermatozoa yang dihasilkan beberapa sapi pejantan madura relatif berdampak
Tabel 10. Potensi produksi semen beku sapi pejantan madura di BIB Lembang pada musim hujan dan musim kemarau

\begin{tabular}{|c|c|c|}
\hline \multirow[t]{2}{*}{ Sapi } & Musim Hujan & Musim Kemarau \\
\hline & \multicolumn{2}{|c|}{ Straw } \\
\hline 1 & $139.53 \pm 61.89 b$ & $136.38 \pm 55.04 b$ \\
\hline 2 & $153.31 \pm 76.51 b$ & $99.14 \pm 64.46 \mathrm{a}$ \\
\hline 3 & $151.85 \pm 65.27 \mathrm{~b}$ & $160.25 \pm 59.10 \mathrm{~b}$ \\
\hline 4 & $141.92 \pm 44.24 \mathrm{~b}$ & $141.46 \pm 63.16 b$ \\
\hline 5 & $86.47 \pm 55.80 \mathrm{a}$ & $79.22 \pm 44.52 \mathrm{a}$ \\
\hline
\end{tabular}

Angka yang diikuti huruf berbeda pada kolom yang sama menunjukkan perbedaan nyata berdasarkan pengujian dengan taraf uji 5\%

terhadap potensi produksi semen bekunya. Aisah et al. (2017) menjelaskan bahwa hubungan antara volume dan konsentrasi semen dengan produksi semen beku adalah berkorelasi positif. Semakin tinggi volume semen dan konsentrasi spermatozoa maka semakin tinggi pula produksi semen beku yang dihasilkan.

\section{KESIMPULAN}

Kualitas semen segar dan potensi produksi semen beku beberapa sapi pejantan madura relatif berbeda pada musim hujan dan musim kemarau.

\section{DAFTAR PUSTAKA}

Aisah, S, N. Isnaini \& S. Wahyuningsih. 2017. Kualitas semen segar dan recovery rate sapi bali pada musim yang berbeda. J. Ilmu-Ilmu Peternakan 27(1):63-79.

Arifiantini I. 2012. Teknis Koleksi dan Evaluasi Semen pada Hewan. Institut Pertanian Bogor (IPB)-Press, Bogor.

Ax, R.L, M.R. Dally, B.A. Didion, R.W. Lenz, C.C.Love, D.D Varner, B. Hafez \& M.E. Bellin. 2000. Semen Evaluation. In ESE Hafez (ed). Reproduction in Farm Animal, Ed ke-7. Philadelphia (US): Lippincott Williams \& Wilkins. 365-375.

[BIB] Balai Inseminasi Buatan Lembang. 2015. Laporan Bulanan Data Semen BIB Lembang 2015. Balai Inseminasi Buatan Lembang, Bandung.

[BPS] Badan Pusat Statistik. 2016. Kabupaten Bandung Barat dalam Angka. Badan Pusat Statistik Kabupaten Bandung Barat, Bandung.

Campbell, J.R, K.L. Campbell \& M.D. Kenealy. 2003a. Anatomy and Physiology of Reproduction and Related Technologies in Farm Mammals: in Animal Sciences Ed ke-4. Mc Graw-Hill, New York.

Campbell, J.R, K.L Campbell \& M.D. Kenealy. 2003b. Artificial Insemination: in Animal Sciences Ed ke-4. Mc Graw-Hill, New York

Cotter, P.Z, H.A. Goolsby \& S.D. Prien. 2005. Preliminary evaluation of a unique freezing technology for bovine sperm cryopreservation. Reprod Dom Anim. 40:98-99.

[Ditjenpkh] Direktorat Jenderal Peternakan BIB Lembang. 2018. Kondisi Geografis dan Komponen Pendukung [internet]. [diakses pada 10 April 2018]. 
[dapat diunduh] http://www.biblembang.ditjenpkh. pertanian.go.id/ read/8/sejarah.

Feradis. 2010. Bioteknologi Reproduksi pada Ternak. Alfabeta, Bandung

Garner, D.L \& E.S.E. Hafez. (2000). Spermatozoa and Seminal Plasma. In Reproduction in Farm Animal Ed ke-7. In ESE Hafez (ed). Lea and Febiger Publishing, Philadelphia

Ismaya. 2014. Bioteknologi Inseminasi Buatan pada Sapi dan Kerbau. Yogyakarta (ID): UGM Press, Jogyakarta

Nurgiartiningsih, V.M.A. 2010. Sistem breeding dan performans hasil sapi madura di Madura. J Tern Trop 11(2):23-31.

Khairi, F, A. Muktiani \& Y.S Ondho. 2014. Pengaruh suplementasi vitamin e, mineral selenium dan zink terhadap konsumsi nutrien, produksi dan kualitas semen sapi simmental. Agripet. 14(1):6-16.

Koivisto, M.B, M.T. Costa, S.H. Perri \& W.R.R. Vicente. 2009. The effect of season on semen characteristics and freezability in bos indicus and bos taurus bulls in the southeastern region of brazil. Reprod Dom Anim. 44(2):587-592.

Lestari, S.D, T.R. Tagama \& D.M. Saleh. 2013. Profil produksi semen segar sapi simmental pada tingkat umur yang berbeda di balai inseminasi buatan Lembang Jawa Barat. J Ilmu Petern. 1(3):897-906.
Situmorang, P. 2002. The effects of inclusion of exogenous phospolipid- intrisdiluent containing a diferent level of egg yolk on the viability of bull spermatozoa. JITV. 7(3):181-187.

Standar Operasional Prosedur. 2010. Pemeriksaan dan Pengujian Mutu Semen. Balai Insemiasi Buatan Lembang, Bandung

Sugiarti, T, E. Triwulanningsih, P. Situmorang, R.G. Sianturi \& D.A. Kusumaningrum. 2004. Penggunaan Katalase dalam Produksi Semen Dingin Sapi: Seminar Nasional Teknologi Peternakan dan Veteriner. Balai Penelitian Ternak, Bogor

Sunami, S, N. Isnaini \& S. Wahjuningsih. 2017. Kualitas semen segar dan recovery rate (RR) sapi Limousin pada musim yang berbeda. J Tern Trop. 18(1): 36-50.

Susilawati, T. 2013. Pedoman Inseminasi Buatan pada Ternak. Univ Brawijaya Press, Malang

Wijono, D.B \& B. Setiadi. 2004. Potensi dan keragaman sumberdaya genetik sapi Madura. Lokakarya Nasional Sapi Potong. 42-52.

Zulyazaini, Dasrul, S. Wahyuni, M. Akmal \& M.A.N. Abdullah. 2016. Karakteristik semen dan komposisi kimia plasma seminalis sapi aceh yang dipelihara di BIBD Saree Aceh Besar. Agripet. 16(2):121-130. 